\title{
Lord Holland's Portuguese Library
}

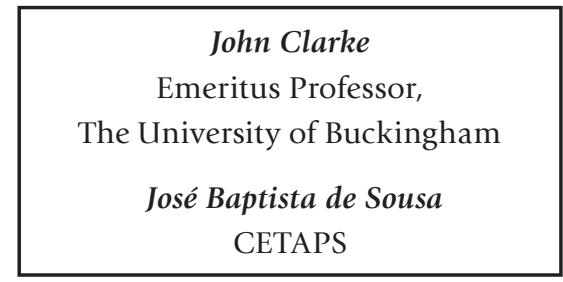

See what D. J.-M. de Sousa says in this regard in his edition of Os Lusíadas, when he mentions a Friar Josepe Índio, the owner as he then was of Lord Holland's celebrated copy. ${ }^{1}$ (Garrett: 205)

ord Holland's initial response to Portugal was one of disdain, a reaction that may be attributed to exposure to a widely held Spanish prejudice rather than to any personal antipathy. Yet, with the passing years, Holland's attitude changed into one of 'love' and 'affection', to quote his own words in a speech to the House of Lords in July 1828 (The Times, July 17, 1828: 6). ${ }^{2}$ Indeed, while Holland may not qualify as a 'Lusophile', he was certainly a friend of Portugal, even if this long lasting relationship is someti-

1. "Veja o que a este respeito diz o Sr. D. J.-M de Souza na sua edição dos Lus.[íadas] quando falla de um Fray Josep Indio, proprietario, que foi, do famoso exemplar de lord Holland." (Our translation).

2. Henry Richard Vassall-Fox (1773-1840), 3rd Baron of Holland of Holland and Holland of Foxley, English Whig politician, statesman and hispanist. He was the grandson son of Henry Fox, 1st Lord Holland, and his wife Lady Caroline Lennox, the eldest daughter of Charles Lennox, 2nd Duke of Richmond, a grandson of Charles II. Holland was the nephew of Charles James Fox, the famous Whig politician, who was responsible for his education. In 1797, Holland married Elizabeth Vassall (1771-1845), whose marriage to Sir Godfrey Webster had just been dissolved. Elizabeth was the daughter of Richard Vassall (1732-1795), who had extensive estates in Jamaica, by Mary Clarke (1747-1835), known as Lady Affleck after her second marriage to Sir Gilbert Affleck (1740-1808), 2nd Baronet, of Dalham Hall. 
mes difficult to trace. Apart from John of Gaunt or George Canning, there is probably no other example in the long history of relations between the two countries of an English politician who devoted himself to Portugal as Holland did. The impressive collection of Portuguese books and manuscripts that Holland collected throughout his long and rewarding life is probably one of the strongest evidence of such affection. The Portuguese section at the Holland House Library, was often consulted by several celebrated authors like Robert Southey (1774-1843), John Adamson (1787-1855), Morgado de Mateus ${ }^{3}$ and perhaps even Almeida Garrett (1799-1854), the reputed founder of Portuguese Romanticism. This article is a contribution to the study of Lord Holland's Portuguese Library, from the perspective of the history of books and libraries, and also investigates the importance of this Library to the study and diffusion of the Portuguese culture and literature in England in the first half of the nineteenth century.

It was probably the Spanish poet Manuel José Quintana y Lorenzo (1772-1857) who introduced Lord Holland to Portuguese literature during his visit to Madrid in 1803. Quintana's admission in a letter to Holland on 7 February 1805 that he could not read "(...) any of their books, except for Camões's works (...)", suggests that Holland had at least some acquaintance with the master of the Portuguese Renaissance literature (Quintana to Holland, Madrid, 7 Feb. 1805', apud Alonso: 317). ${ }^{4}$ Sometime earlier, probably also in 1803, Lady Holland requested Sir Henry Chamberlain (1773-1829), British Consul at Lisbon, to obtain copies of correspondence thought to be preserved at the Torre do Tombo (National Archives) (British Library, Holland House Papers, MSS Add. 51632, Papers Relative to Portugal: H. Chamberlain to Lady Holland, f. $3{ }^{\text {r }}, 29$ Nov. 1803). ${ }^{5}$

3. D. José Maria do Carmo de Sousa Botelho Mourão e Vasconcelos (1758-1825), 5th Morgado de Mateus, Portuguese diplomatist and editor, the son of D. Luís António de Sousa Botelho Morão (17221798), Governor of São Paulo, by his wife, D. Leonor Ana Luísa José de Portugal (1722-c.1806). José Maria was Minister at Stockholm, Copenhagen, Paris and St Petersburg. He married twice: firstly, in 1783, to D. Maria Teresa Soares de Noronha (1760-1785), daughter of D. José de Noronha and D. Mariana Isabel das Montanhas Ribeiro Soares, who bored him one son, D. José Luís de Sousa Botelho Mourão e Vasconcelos (1785-1855), 1st Conde de Vila Real; the second, on 17 October 1802, to Adélaïde Marie Emilie Filleul, who became known as Madame de Sousa (1761-1836).

4. "Yo no puedo leer libro ninguno suyo, sino las obras de Camoens." (Our translation).

5. Sir Henry Chamberlain (1773-1829), Consul General and Chargé d'Affaires at Lisbon and Rio de Janeiro. 
This request - possibly on Dr John Allen's behalf - corresponds to the Hollands' first reported interest in things Portuguese. ${ }^{6}$ As Chamberlain's answer to Lady Holland is dated 29 November 1803 together with the fact that the request would have required Chamberlain to make enquiries about the location of these documents, suggests that Lady Holland's letter preceded the reply perhaps by some months.

Lord Holland's first recorded interest in Portuguese books also dates to 1803, when he wrote from Madrid to Chamberlain, asking for a copy of Diogo Machado's Bibliotheca Lusitana, a catalogue of Portuguese authors accompanied by biographical notices. ${ }^{7}$ Chamberlain replied on 24 November 1803, explaining that he had sent a copy through $M$. Couëssin, a French traveller about to leave for Madrid. (BL, HHP, MSS Add. 51632, Papers Relative to Portugal: H. Chamberlain to Lord Holland, ff. $1^{\mathrm{r}}-\left[1^{\mathrm{v}}\right], 24$ Nov. 1803) During his visit to Portugal in 1804-1805, while confined to his home for almost a month by poor weather and Lady Holland's illness, Holland found it difficult to keep himself amused. (BL, HHP, MSS Add. 51737, Lord Holland to Caroline Fox, f. 165, 16 Jan. 1805) He read a lot, notably Robert Southey's translation of Amadis of Gaul, a romance of chivalry usually attributed to the Portuguese troubadour Joham de Lobeira (1261-1325), though sometimes to Vasco de Lobeira (†1403), knighted after the famous Battle of Aljubarrota (1385). Spanish scholars claim the author is unknown. "What an odd man that Southey is $(\ldots)$ ", Holland wrote to his sister on 10 January, "(...) full of genius imagination \& most wonderfully diligent." (BL, HHP, MSS Add. 51737, Lord Holland to Caroline Fox, f. 163ㄹ, 10 Jan. 1805)

Lord Holland's interest in Portuguese books is also suggested

6. John Allen (1771-1843), Scottish physician, historian and political essayist, graduated in medicine in 1791 at the University of Edinburgh. He accompanied the Hollands to the Peninsula in 1802 in the quality of private physician and secretary, a position he held for the rest of his life.

7. Diogo Barbosa Machado, Bibliotheca Lusitana: Historica, Critica, e Chronologia. 4 vols. (Lisboa Occidental: Na Officina de Antonio Isidoro da Fonseca, 1741-1759).

8. Southey's translation was made from the Spanish Garci Rodríguez de Montalvo, editor of the first printed version, Los quatro libros del Virtuoso caballero Amadís de Gaula (Zaragoza: Coci, 1508), who claimed to have edited the text from old manuscripts (Southey, "Preface" to Amadis of Gaul: 123 24). The translation was made from a later edition, as the only known copy of the first edition, preserved at the British Library, was discovered at Ferrara in 1872 by the bibliophile and book collector Edwin Tross. 
by the frequent presence at Holland House of Richard Heber (17731833), MP for Oxford University and a famous bibliophile who owned an extensive Portuguese library. Heber was in a dinner at Kensington on 6 December 1821, also attended by D. José de Sousa Botelho, the future Conde de Vila Real, ${ }^{9}$ Lady Affleck (Lady Holland's mother), Mr Adair ${ }^{10} \mathrm{Mr}$ and Mrs Smith and Mr Charles Ellis. (BL, HHP, MSS Add. 51953, Dinner Books: 1819-1825, f. 75, 6 Dec. 1821) Lady Holland said of Heber: "His memory is quite remarkable, and his ready application of verses and stories smart and brisk", (Vassall, apud Ilchester, Chronicles: 31) while Henry Edward Fox, later fourth Lord Holland ${ }^{11}$ who set by his side in a dinner on 27 January 1823, wrote in his journal:

He is good-natured and has acquired a good deal with all his book-collecting and reading, but is rather in the Oxford style of humbug, which is so very odious. I rather like him. He is very much given to drinking and eating, which his friends!!! say has deadened his understanding. (154)

The importance of Heber's Portuguese collection is acknowledged in John Adamson's preface to his Memoirs of the Life and Writings of Luis de Camoens: "(...) the name of his friend Mr Gooden, and that of Mr Heber, to whose stores of Portuguese literature he has had fee access." (1: xii) Heber's fabulous library was sold after his death in several auctions in 1834-1835, while an impressive catalogue was printed in 12 parts (3 volumes) as Bibliotheca Heberiana. During his exile in Britain between 1828 and 1831, Almeida Garrett often visited the libraries of the British Museum, Heber and Gooden, whose

9. D. José Luís de Sousa Botelho Mourão e Vasconcelos (1785-1855), 1st Conde de Vila Real and 6th Morgado de Mateus, Portuguese diplomat and statesman, the son of D. José Maria do Carmo de Sousa Botelho Mourão e Vasconcelos (1758-1825), 5th Morgado de Mateus, by his first wife, D. Maria Teresa Soares de Noronha (1760-1785). He married in 1811 D. Teresa Frederica Cristina de Sousa e Holstein (1786-1841), the Duque de Palmela's sister.

10. Sir Robert Adair (1763-1855), British diplomat and politician, son of Robert Adair, surgeon to George III.

11. Henry Edward Fox (1802-1859), afterwards 4th Lord Holland, the son of Henry Richard Vassall-Fox and his wife Elizabeth Vassall. He was born at Holland House on 7 March 1802 and died at Naples on 8 December 1859. Henry Edward married on 9 May 1833 Mary Augusta Coventry (1812-1889), daughter of George William Coventry, 8th Earl of Coventry, by Lady Mary Beauclerk. The couple had no issue and the barony became extinct. 
Portuguese collections proved useful when composing ballads such as Adozinda, a verse romance inspired by Walter Scott's minstrelsies. (Sousa: 118$)^{12}$ It is also possible that Garrett, like so many other middle-class Italian or Spanish émigrés, may have occasionally visited Holland House while attaché to the Portuguese Legation in London (1829-1831), but we could not hitherto find any clear evidence to support this conclusion.

Like his father, Stephen Fox, ${ }^{13}$ Henry Richard Fox was an avid book collector, although, as Lord Ilchester observed in a typewritten "Note on the Holland House Library" preserved at the British Library, "(...) Lord Holland could not afford rarities, except at low prices", especially after the "(...) diminution in Lady Holland's income from the West Indies as a result of the Abolition of the Slave Trade." (BL, Hodgson Papers, MSS Add. 54721, Miscellaneous Papers Relating to Holland House, by Lord Ilchester: Note on the Holland House Library, f. $1^{\mathrm{r}}$. ${ }^{14}$ Because of gambling debts Stephen Fox left at his death on 16 December 1774, his widow was forced to lease Holland House and move with her children to Ampthill Park, Bedfordshire, while an auction was held by Christie towards the end of 1775 to sell all furniture and books. (Sousa and Clarke: 129) The surviving A Catalogue of the Noble, Select and Elegant Library, of the Rt. Hon. Stephen Lord Holland, suggests that, unlike his son who became a devoted bibliophile, Stephen Fox was rather a compulsive buyer, apparently without any criteria. In the course of his life, the third Lord Holland collected an impressive library, including several rare

12. James Gooden (1773-1851), British merchant in the Portuguese and Brazilian trade with literary and antiquary tastes. Gooden's impressive collection of Portuguese books and manuscripts was consulted by Robert Southey, John Adamson and Almeida Garrett. In the preface to his History of Brazil, Southey thanks Gooden for lending him a life of João de Almeida and other manuscripts. (2: [i]) John Adamson, who must have met Gooden at Oporto, makes a similar acknowledgement in his Bibliotheca Lusitana, thanking Gooden, together with the King's Librarian, Heber and Southey, for assisting him with his studies on Portuguese literature. (iii) Sir Francis Sacheverell Darwin (17861859), who visited Portugal in 1808 on his way to Spain, mentions "(...) a Mr Gooden, a very polite merchant", with whom he "dined every day". A few days later, at Lisbon, Darwin reencountered Gooden, who had sailed round from Oporto. $(8,13)$

13. Stephen Fox (1745-1774), 2nd Baron Holland of Holland and Holland of Foxley, Peer, the eldest son of Henry Fox (1705-1774), 1st Baron Holland of Foxley, and his wife Lady Georgiana Carolina Fox, née Lennox (1723-1774), 1st Baroness Holland of Holland. Stephen, or "Ste" as he was known in intimacy, married in 1766 Lady Mary Fitzpatrick (1746/7-1778).

14. Ilchester's typewritten text on the Holland House Library with MS corrections, possibly for inclusion in the auction catalogue. 
books and manuscripts. When Faulkner published his History and Antiquities of Kensington in 1820, Holland's Library, which had been assembled since its owner moved to Kensington in 1797, contained an estimated 15,000 volumes. According to Faulkner:

Its value does not consist in the extreme variety, or extraordinary splendour of the editions, nor are the bindings so sumptuous as in many modern libraries. But on the other hand, it is not deficient in specimens of each kind, and having been collected recently, it contains few works but such as are useful for perusal or reference. The series of French and English History and Memoirs is said to be very complete, and there are few private libraries in England which contain so good and so large a selection of Spanish and Italian authors, particularly Spanish law books. (153)

The Library, whose main section occupied the whole western wing, also contained an extensive collection of Portuguese books and manuscripts, which Southey consulted while writing on the literature and history of the Peninsula (Sanders 2:174) and John Adamson his Memoirs of the Life and Writings of Luís de Camoens, as he admitted in the preface: "(...) to Lord Holland, for his attention that his Lordship would allow the author to inspect the extremely rare and curious copy of the first edition of the Lusiad at Holland House $(. . .)^{\prime \prime}$. (1:xii) The importance of Holland's collection of Portuguese and Spanish books and manuscripts is also stressed in an article in Scribner's Monthly, while comparing it - as well as that preserved at the British Museum - to the splendid collection bequeathed by the American Hispanist George Ticknor (1791-1871) to the Boston Public Library. (150)

Among the rarities owned by Lord Holland were several Spanish manuscripts dating from 1542 to 1610 as well as books, folios, tracts and pamphlets valued at $£ 3000$, miscellaneous and foreign books estimated at $£ 5000$ and several engravings from the Morgado de Mateus' edition of Os Lusíadas by Luís de Camões (Paris, 1817), valued at $£ 1000$. (BL, Hodgson Papers, MSS Add. 54721, Miscellaneous Papers Relating to Holland House, by Lord Ilchester: Lists of books saved from the Holland House Library after the bombings and fire 


\section{ESTUDOS/ESSAYS}

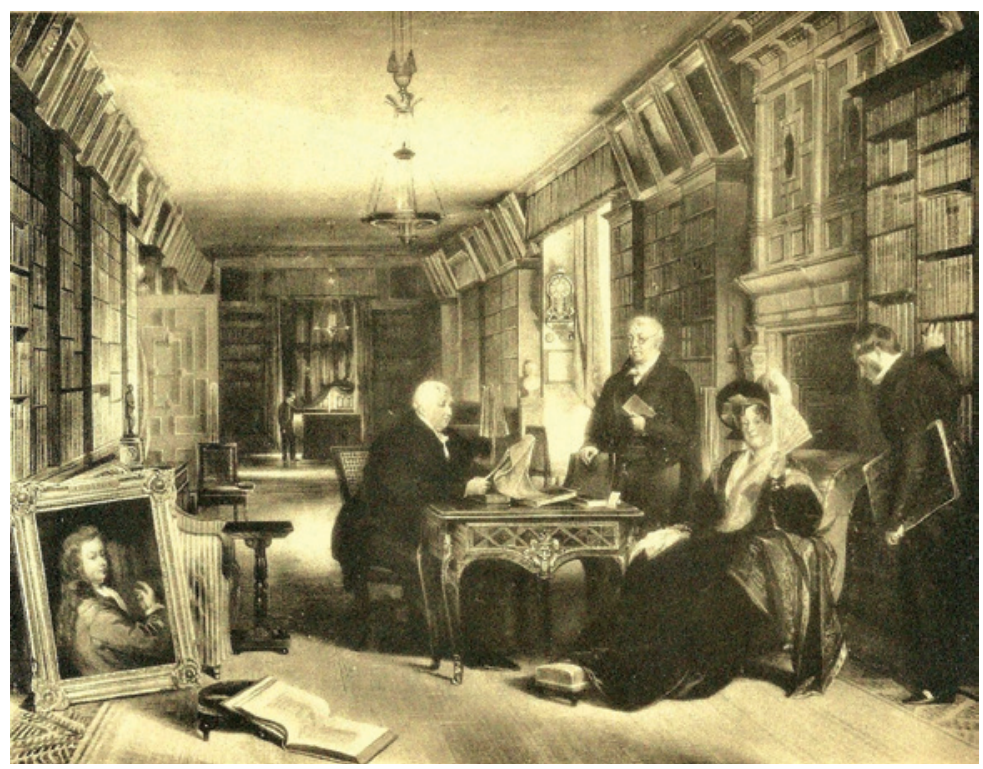

The family picture: the library of Holland House / C. R. Leslie, featuring Henry Richard Fox, Dr John Allen, Lady Elizabeth Vassall and Edgar Dogget, "Holland House and its Owners", The Graphic, 12 October 1889.

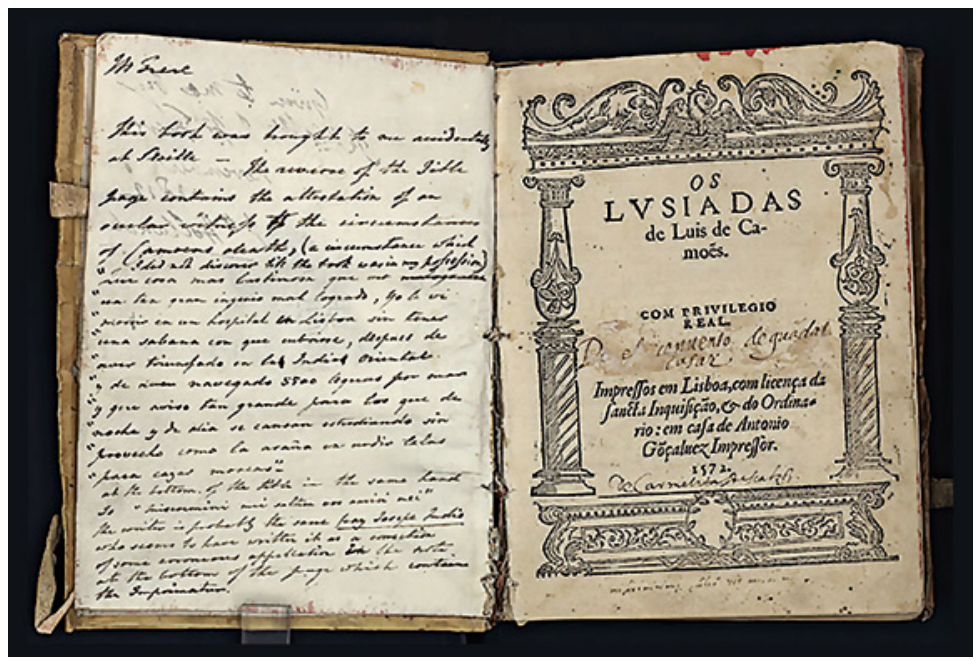

Title page of Os Lusíadas (1572), copy formerly owned by Lord Holland 
(4), ff. $\left.1^{\mathrm{r}}-6^{\mathrm{r}}\right)^{15}$

Another rarity was the copy of Deliciae lusitano hispanica, ${ }^{16}$ by the Portuguese André de Resende, ${ }^{17}$ presented to Holland by Archbishop Francisco do Cenáculo on 8 July 1809, when the Hollands stopped at Évora on their way from Seville to Lisbon. ${ }^{18}$ In his own words, "the Archbishop made me a present of a book on the antiquities \& ancient divisions of Lusitania - by Resendius - \& Renatius Vasconcellus - Cologne 1613". (BL, HHP, MSS Add. 51861, Lord Holland's travel journals: 1809, f. $8^{v}$, July 9)

Perhaps the most valuable book was the above mentioned editio princeps of Os Lusíadas (1572), offered to Holland by John Hookham Frere in $1812 .{ }^{19}$ The book was unique in that on the reverse of the title page there was a manuscript account of Camões' life by Friar Joseph Indio, a Brazilian Indian converted to Christianity and taken to Portugal in Pedro Álvares Cabral's fleet, who allegedly had assisted the poet in his last days and to whom Camões had given his own

15. It consists in a folder with several lists of books sold at Hodgson \& Co., of 115 Chancery Lane, or either kept by Lord Ilchester, with some written notes by the later.

16. Deliciae lusitano hispanica. inquibus continentur de magnitudine Hispanici Imperij Relatio... Ab Andrea Resendio Collectae (Coloniae Agrippinae apud Gerhardum Greuenbruch, 1613), of which there is a copy in the Biblioteca Nacional (RES. 715 P.).

17. André de Resende (1498-1573), Portuguese humanist and antiquary described as the founder of Portuguese archaeology, son of Pêro Vaz de Resende and of Ângela Leonor de Góis. Orphaned at an early age, Resende entered the Dominican Order aged ten. He attended the Spanish Universities of Alcalá de Henares and Salamanca, obtaining a doctorate from the latter. By 1533 he had abandoned the Dominican habit to embrace academic life, teaching at the Universities of Paris, Lisbon and Coimbra, and publishing a number of works, mostly on archaeology. Died in Évora, 1573, and buried in the cloister of the Convent of São Domingos.

18. D. Francisco Manuel do Cenáculo (1724-1814), Archbishop of Évora, a Franciscan friar of humble origin and a protégé of Pombal, son of José Martins, a locksmith, by Antónia Maria. Cenáculo was Preceptor to the Infant D. José (1761-1788), first son of the Infanta D. Maria, later Queen Maria I. Following Pombal's disgrace in 1777, Cenáculo was forced to resign his public posts and returned to Beja to resume the bishopric, dedicating himself to public education and to archaeological activities. In 1802, twenty-five years after Pombal's dismissal, Cenáculo was appointed Archbishop of Évora, where he created a Museum and a Public Library. He was also responsible for the organisation of the Library of the Convent of Jesus in Lisbon - now the main collection of the Academy of Sciences - and also gave some of his own books to the Royal Public Library of Lisbon, now the National Library.

19. John Hookham Frere (1769-1846), English diplomat, son of the archaeologist John Frere (1740-1807), of Roydon Hall, Norfolk, by his wife Jane Hookham. Extraordinary Envoy and Minister Plenipotentiary to Lisbon in 1800, Frere was transferred to Madrid in 1802 and there he remained until 1804. At the outbreak of the Peninsular War, Frere returned to Spain as Extraordinary Envoy and Minister Plenipotentiary, a position held from October 1808 to 31 July 1809 . He was then recalled to England to answer for responsibility for the British defeat at Coruna (16 January 1809) and was replaced by Richard Wesley (1760-1842), Marquess of Wellesley. (Bindoff, Smith, and Webster: 89, 142) 
copy. ${ }^{20}$ This information was confirmed by the Morgado de Mateus, who in his 1817 edition of Os Lusíadas noted that Holland had kindly lent him his copy. (vi, lxiii, xxiii) Mateus explained that Indio had taken the book to the Carmelite Convent of Guadalajara in Spain. Frere probably acquired the book in Seville, during the course of one of his diplomatic missions.

Marie Liechtenstein ${ }^{21}$ the adopted daughter of the fourth Lord Holland, gives a full description of the Holland's copy of Os Lusiadas:

Os Lvsiadas de Luis de Camões. Com previlegio real. Impressos em Lisboa, com licença de santa Inquisição, et de Ordinario: em casa de Antonio Gõçaluez, Impressor, 1572; small 4to. On the title-page: "De el convento de Guadalcazara de Carmelita descalzos". On the reverse there is a MS. memorandum by Fray Joseph Indio, which is embodied in the following note by John Hockham Frere on the reverse of the fly-leaf: -

"This book was brought to me accidently at Seville. The reverse of the title-page contains the attestation of an ocular witness to the circumstances of Camoens' death (a circumstance which I did not discover till the book was in my possession): - Que cosa mas lastimosa que ver un tan gran ingenio mal logrado yo lo vi morir en un hospital en Lisboa sin tener una savana con que cubrirse, despues de aver triunfado en la India Oriental y de aver navegado 5500 leguas por mar y que aviso tan grande para los que de noche y de dia se causan estudiando sin provecho como lo avaña en

20. According to a tradition, Luís de Camões died in misery in 1580, either in a house at the Calçada de Sant'Ana or in the Hospital of Sant'Ana, and buried at the Cemetery of the Convent of Sant'Ana, in the top of the Calçada de Sant'Ana, partially destroyed during the great Lisbon earthquake in 1755. However, it is more likely that he was buried at the pauper cemetery at the Calçada de Sant'Ana in front of the building now occupied by INATEL Foundation, and where it remained until 1833, when the new cemeteries of Prazeres and Alto de São João in the outskirts of Lisbon were extended. (Ribeiro: 141-48; Archivo Pitoresco 4:22 (1861): 175-76; Gazeta de Lisboa, 1833, 11 Jun.: 735; Chronica Constitucional de Lisboa 1822, 23 Out. and 28 Nov.: 412, 600)

21. Marie Henriette Adélaïde von Liechtenstein, née Fox (1850-1878), the adopted daughter of Henry Edward Fox (1802-1859), 4th Lord Holland, and his wife Lady Mary Augusta Coventry (1812-1889). Marie had been presented to them in 1851 by Dr Séguin, a family friend, who claimed he had discovered her in Paris. Marie was baptized at the Church of St Augustine as Marie Henriette Adélaïde, the daughter of Victoire Magny of Soissons, though her paternity was never revealed. The adoption raised suspicions, especially in Lady Holland, that Marie could be Holland's illegitimate child by his servant, a theory strengthened by the fact that relations between Marie and her adoptive mother were far from cordial. Marie Fox married Prince Louis von Liechtenstein at Holland House on 27 June 1872. 
ordrir telas para coger moscas ${ }^{22}$ - At the bottom of the title, in the same hand, is: - Miseremini mei saltem vos amici mei. The writer is probably the same Fray Joseph Indio, who seems to have written it as a correction of some erroneous appellation in the note at the bottom of the page, which contains the Imprimateur. - J. H. Frere."

On the right of the fly-leaf: - "Given to me by Rt. Hon. J. H. Frere, November 1812. V." Holland." (177-78).

When Ilchester published The Home of the Hollands in 1937, he stated that Os Lusíadas was still in the Holland House Library. (255) This was the last mention of the book for many years and some feared that it had been destroyed in the bombing of 28 September 1940. Although part of Library of Holland House survived the fire that followed the German attack, according to Ilchester's "Note on the Holland House Library", of "(...) the many volumes which reposed on its shelves for more than one hundred years, half were destroyed or so badly damaged by fire and water, as to render their preservation a matter of grave doubt." (BL, Hodgson Papers, MSS Add. 54721, Miscellaneous Papers Relating to Holland House, by Lord Ilchester: Note on the Holland House Library, f. $1^{\mathrm{r}}$.) Ilchester also observed:

The hydrants, brought into action within a few minutes, were useless as there was no water. Fire engines were at premium, and by the time a main in Notting Hill had been tapped, the fire had spread to the roof of the Library, though it proved possible to save the South end of the long room. But water is just as destructive as fire, and the heavy rain which felled down on the roofless Library, left a mass of books hopelessly soaked and sodden, before any arrangement for removal was possible. (ibidem)

At the outbreak of the Second World War, Ilchester may have removed Os Lusíadas from Holland House and taken it to Melbury, as he did with the collection of manuscripts forming the Holland House Papers, pictures, ceramics and several pieces of furniture.

22. There is a translation of Joseph Indio's text by Isaac Disraeli: "What a lamentable thing to see so great a genius so ill rewarded! I saw him die in an hospital in Lisbon, without having a sheet or shroud, una sauana, to cover him, after having triumphed in the East Indies, and sailed 5500 leagues! What good advice for those who weary themselves night and day in study without profit!". (1:30) 
(Hudson: 125; Keppel xii) It is not known whether this is what happened or whether the copy was rescued from the flames and included in the lot of books sold in an auction held in July 1947 at Hodgson \& Co. - which brought Ilchester the sum of $£ 5,280$. Yet Holland's copy of Os Lusíadas survived and in 1966, it was acquired by Harry Ransom Humanities Research Center, University of Texas, Austin, where it is now preserved. But although the book went to Texas in the 1960s, it was only on 4 March 1970 that the purchase was officially concluded, through Lew David Feldman, a bookseller from El Dieff House, N.Y. Richard Oram, Associate Director and Hobby Foundation Librarian at Harry Ransom Center, with whom I had some correspondence recently, assured me that although he had been on the trail of the Feldman archive for years, he could not find any information about the history of the book prior to its acquisition by the University of Texas. Doubts continue as to the veracity of Joseph Indio's account of Camões.

\section{Works Cited}

\section{I) Manuscripts}

BL, HHP, MSS Add. 51632, Papers Relative to Portugal: H. Chamberlain to Lord Holland, ff. $1^{\mathrm{r}}-\left[1^{\mathrm{v}}\right]$ (24 Nov. 1803).

BL, HHP, MSS Add. 51737, Lord Holland to Caroline Fox, f. $163^{\mathrm{v}}$ (10 Jan. 1805).

BL, HHP, MSS Add. 51861, Lord Holland's Travel Journals: 1809, f. $8^{v}$ (9 July 1809).

BL, HHP, MSS Add. 51953, Dinner Books: 1819-1825, f. 75 (6 Dec. 1821).

BL, HODG, MSS Add. 54721, Miscellaneous Papers Relating to Holland House, by Lord Ilchester: Lists of books saved from the Holland House Library after the bombings and fire (4), ff. $1^{\mathrm{r}}-6^{\mathrm{r}}$.

BL, HODG, MSS Add. 54721, Miscellaneous Papers Relating to Holland House / Lord Ilchester: Note on the Holland House Library, f. $1^{\mathrm{r}}$.

\section{II) Printed Sources}

Anonymous. "The Boston Public Library." Scribner's Monthly: an Illustrated Magazine for the People 3:2 (Dec. 1871): 150-156. 


\section{REAP/JAPS 26}

---. "Casa Onde Consta que Morou e Falleceu Camões." Archivo Pitoresco: Semanario Illustrado 4:22 (1861), 175-76.

Adamson, John. "Preface" to Memoirs of the Life and Writings of Luís de Camoens. 2 vols. London: Printed for Longman, Hurst, Rees, 1820.

---. Bibliotheca Lusitana: or Catalogue of Books and Tracts Relative to the History, Literature, and Poetry, of Portugal. Newcastle on Tyne: Printed by T. and J. Hodgson, 1836.

Alonso, Manuel Moreno. "Principios políticos y razones personales para la reforma del estado en España (1805-1840): (De la correspondencia inédita de M. J. Quintana con Lord Holland)." Revista de Estudios Políticos 70 (Oct.-Dic. 1990): 289-338.

Bindoff, S. T., E. F. Malcolm Smith, and Webster C. K. (eds.) British Diplomatic Representatives 1789-1852. London: The Royal Historical Society, 1934.

Chronica Constitucional de Lisboa, 1833, 23 Out. and 28 Nov.: 412, 600.

Clarke, John and José Baptista de Sousa. "A 'Portuguese Garden' in Kensington." Journal of Anglo-Portuguese Studies, 25 (2016): 123-145.

Darwin, Francis Sacheverell. Travels in Spain and the East, 1808-1810. Cambridge: University Press, 1927.

Disraeli, Isaac. The Works of Disraeli. New Edition. 3 vols. London: Routledge, Warnes and Routledge, 1859.

Faulkner, Thomas. History and Antiquities of Kensington. London: Printed for T. Egerton, 1820.

Garrett, João Baptista de Almeida. Notes to the Fourth Edition of Camões. Lisboa: Casa da Viúva Bertrand e Filhos, 1854.

Gazeta de Lisboa, 1833, 11 Jun.: 735.

Holland, Henry Edward Fox, Fourth Baron of. The Journal of Henry Edward Fox (afterwards fourth and last Lord Holland) 1818-1830. London: Thornton Butterworth, 1823.

Holland, Henry Richard Vassall-Fox, Third Baron of. "Speech in the House of Lords on Foreign Affairs". The Times, July 17, 1828: 6.

Hudson, Derek. Holland House in Kensington. London: Peter Davies, 1967.

Ilchester, Giles Stephen Holland Fox-Strangways, 6th Earl of. Chronicles of Holland House 1820-1900. New York: E. P. Dutton, 1938.

---. The Home of the Hollands. New York: E. P. Dutton, 1937.

Keppel, Sonia. The Sovereign Lady: a Life of Elizabeth Vassall, Third Lady Holland, With Her Family. London: Hamish Hamilton, 1974.

Liechtenstein, Marie, Princess, Holland House. 2 vols. London: Macmillan and Co., 1874.

Mateus, José Maria do Carmo de Sousa Botelho Mourão e Vasconcelos, Morgado de. "Advertencia" to Os Lusiadas, Poema Epico de Luis de Camões, Nova Edição Correcta, e Dada á Luz, Conforme á de 1817, in-4. ${ }^{\circ}$, por Dom Joze Maria de Souza-Botelho, Morgado de Matteus, Socio da Academia Real das Sciencias de Lisboa. Paris: Officina Typographica de Firmino Didot, 1819, [i]-xlv.

Ribeiro, Victor. "O Cemiterio dos Pobres ou de Santa Anna (1566-1834)." 


\section{ESTUDOS/ESSAYS}

Archivo Historico Portuguez, 1907: 141-48.

Sanders, Lloyd. The Holland House Circle. London: Methuen \& Co., 1908: 223.

Sousa, José Baptista de. Almeida Garrett (1799-1854) the Founder of Portuguese Romanticism: a Study in Anglo-Portuguese Cultural Interaction. Lewiston: Edwin Mellen, 2011.

Southey, Robert. "Preface". Amadis of Gaul. 4 vols. London: Printed by N. Biggs... for T. N. Longman and O. Rees, 1803, 1: [i]-xxxvi.

---. "Preface" to History of Brazil. 3 vols. London: Printed for Longman, Hurst, Rees, Orme, and Brown, 1810-1819, 2: [i-iv]). 